\title{
ISOLASI DAN KARAKTERISASI ASAM HUMAT DARI TANAH GAMBUT
}

\author{
Atik Rahmawati \\ Prodi Tadris Kimia Fakultas Tarbiyah IAIN Walisongo
}

\begin{abstract}
Abstrak
Telah dilakukan penelitian tentang isolasi dan karakterisasi asam humat hasil isolasi tanah gambut yang berasal dari Desa Sambutan, Kecamatan Samarinda Ilir, Samarinda, Kalimantan Timur.

Isolasi asam humat dari tanah gambut menggunakan metode ekstraksi alkali, pemurnian dan penentuan kandungan gugus fungsional asam humat secara titrasi potensiometri.

Hasil penelitian menunjukkan gugus fungsional utama asam humat hasil isolasi tanah gambut adalah gugus - $\mathrm{COOH}$ dan gugus -OH. Secara kuantitatif kandungan gugus fungsional tersebut masing-masing sebesar 426,2 $\mathrm{cmol} / \mathrm{kg}$ (gugus - $\mathrm{COOH}$ ), 289,6 cmol/kg (gugus $-\mathrm{OH}$ fenolat) dan $37,0 \mathrm{cmol} / \mathrm{kg}$ (gugus $-\mathrm{OH}$ alkoholat).
\end{abstract}

Kata kunci: Asam humat, Tanah Gambut, Isolasi, Karakterisasi

\section{PENDAHULUAN}

Senyawa humat merupakan senyawa organik alami yang 
terdapat pada berbagai kompartment lingkungan, baik terestrial maupun perairan. Senyawa humat secara tradisional didefinisikan berdasarkan kelarutannya, yaitu : (i) asam fulvat, merupakan bahan humat yang larut dalam air pada semua $\mathrm{pH}$, (ii) asam humat, merupakan bahan humat yang tidak larut pada $\mathrm{pH}$ asam $(\mathrm{pH}<2)$ tetapi larut pada $\mathrm{pH}$ yang lebih tinggi, (iii) humin, merupakan bahan humat yang tidak larut dalam air pada semua nilai $\mathrm{pH}$.

Senyawa humat dapat terbentuk dari dekomposisi jaringan tanaman dan hewan dan dapat ditemukan di lingkungan perairan, tanah dan sedimen. Pembentukan senyawa humat dianggap sebagai proses biologis, namun demikian dengan sifat heterogenitasnya yang tinggi menunjukkan bahwa yang terlibat pada pembentukan senyawa humat tidak hanya enzim-enzim, tetapi juga keberagaman katalis kimia (Huang dkk., 1982 dalam Sanchez dkk., 2000).

Senyawa humat memegang peranan penting dalam mempengaruhi kesuburan tanah dan spesiasi kimia tanah dan perairan. Kandungan senyawa humat dalam tanah bervariasi, mulai dari 0 sampai 10\%. Pada air permukaan, kandungan humat dinyatakan sebagai karbon organik terlarut (dissolved organic carbon : DOC), konsentrasinya bervariasi dari 0,1 hingga $50 \mathrm{mg} / \mathrm{L}$. Pada permukaan air laut kandungan karbon organik terlarut bervariasi dari 0,5 hingga $1,2 \mathrm{mg} / \mathrm{L}$ dan pada air yang lebih dalam (groundwater) bervariasi dari 0,1 hingga $10 \mathrm{mg} / \mathrm{L}$ (Choppin dan Allard, 1985 dalam Gaffney dkk., 1996).

Sejumlah metode isolasi/ekstraksi senyawa humat pada berbagai jenis sampel lingkungan, baik lingkungan tanah, perairan maupun sedimen telah dilaporkan oleh sejumlah peneliti. Stevenson (1982) dalam Aiken dkk. (1985) menyatakan bahwa ada beberapa kriteria metode ekstraksi senyawa humat dari tanah secara ideal yaitu : (1) metode yang digunakan untuk isolasi tidak menimbulkan perubahan bahan-bahan yang diekstraksi, (2) senyawa-senyawa humat yang terekstrak bebas dari kontaminan anorganik seperti lempung dan kation-kation polivalen, (3) proses ekstraksi berlangsung sempurna, dan dapat meng-

118 Jurnal PHENOMENON, Volume 2 Nomor 1, November 2011 
gambarkan fraksi-fraksi dari seluruh rentang berat molekul, (4) metode bersifat universal, dapat diaplikasikan pada semua jenis tanah.

Meskipun banyak penelitian yang telah dilakukan tentang isolasi asam humat dari tanah gambut, namun penelitian tentang hal ini masih memerlukan pengamatan yang lebih jauh mengingat asam humat merupakan bahan organik alami yang sangat heterogen dan kompleks.

Berdasarkan uraian di atas, maka dalam penelitian ini permasalahan pokok yang dikemukakan yaitu : (1) bagaimana isolasi asam humat dari tanah gambut, (2) bagaimana komposisi gugus fungsional utama asam humat yang diekstrak dari tanah gambut yang berasal dari Desa Sambutan, Kecamatan Samarinda Ilir, Kabupaten Samarinda.

\section{LANDASAN TEORI}

\section{Pengertian Senyawa Humat}

Bahan organik tanah dan perairan sering kali dibagi atas bahan terhumifikasi dan tak terhumifikasi. Yang termasuk bahan-bahan tak terhumifikasi adalah senyawa-senyawa dalam tanaman seperti karbohidrat, asam amino, protein, lipid, asam nukleat, dan lignin. Sedangkan fraksi terhumifikasi yang dikenal sebagai humus atau disebut sebagai senyawa humat, dianggap sebagai hasil akhir dekomposisi bahan tanaman dalam tanah (Tan, 1998).

Istilah senyawa humat pertama kali dikemukakan oleh Berzelius pada tahun 1830. Senyawa humat merupakan senyawa makromolekul dengan berat molekul tinggi sebagai hasil peruraian bahan organik tanaman dan berperan penting dalam mempengaruhi sifat-sifat tanah dan spesies kimia dalam tanah dan perairan.

Senyawa humat didefinisikan oleh Aiken dkk. (1985) sebagai kategori umum dari bahan organik tanah heterogen yang terjadi secara alami. Secara umum, senyawa humat dikarakterisasikan berwarna kuning hingga hitam dengan berat molekul 
besar dan bersifat refraktori. Struktur kimianya tidak dapat digambarkan sebagai satu bentuk tunggal karena merupakan campuran yang kompleks dari polielektrolit fenol dan karbohidrat yang bervariasi dari satu molekul ke molekul yang lain (Hayes dan Himes, 1986).

Senyawa humat memiliki berat molekul dan ukuran dalam rentang yang luas, mulai dari beberapa ratus sampai beberapa ratus ribu unit massa atom. Secara umum, asam fulvat memiliki berat molekul lebih rendah dibanding asam humat (Choppin dan Allard, 1985; Stevenson, 1982 dalam Gaffney dkk., 1996). Senyawa humat terdiri atas kerangka karbon dengan karakter aromatis yang tinggi dan memiliki gugus-gugus fungsional yang sebagian besar mengandung atom oksigen (Manahan, 2000). Karakteristik terpenting dari senyawa humat adalah kualitas dan kuantitas gugus fungsionalnya, ukuran molekulnya serta aromatisnya, karena parameter-parameter ini akan menentukan sifat-sifat kimia dan biologi senyawa humat.

\section{Struktur Senyawa Humat}

Model struktur senyawa humat seperti monomer asam humat telah diusulkan dengan pendekatan integrasi berbagai macam metode analisis. Model senyawa humat sangat penting mengingat sebagian besar bahan organik tanah (70-80\%) merupakan senyawa humat dan semua aspek kimia (kapasitas adsorpsi besar, pengompleks logam yang sangat baik, medium bagi mikrobia, dapat menyediakan nutrien) dapat dijelaskan berdasarkan struktur asam humat sebagai senyawa humat yang utama di lingkungan (Ghosh dan Schnitzer, 1980).

Para ahli berpendapat bahwa warna, reaktivitas, dan sifat fisika-kimia senyawa humat ditentukan oleh strukturnya. Meskipun struktur yang tepat belum dapat ditentukan, namun struktur senyawa humat telah diusulkan dengan mendasarkan pada model atau struktur rata-rata senyawa humat yang telah ada, sehingga dapat digunakan untuk studi lebih lanjut. Model struktur senyawa humat yang diusulkan mengacu pada hasil penelitian mengenai komposisi unsur-unsur penyusun, gugus- 
gugus fungsional, produk degradasi, data spektroskopi, dan sifat fisika-kimia senyawa humat.

Sejumlah struktur senyawa humat yang masih merupakan struktur hipotetik telah diajukan oleh beberapa peneliti, seperti Fuch, Dragunov, Flaig dan Stevenson (Stevenson, 1994).

Fuch, seorang ilmuwan Jerman, telah mengusulkan struktur asam humat yang ditunjukkan pada Gambar 2.1. Struktur tersebut merupakan hasil deduksi berbagai penelitian tentang struktur asam humat yang dihasilkan dari batubara, yang terdiri atas sistem cincin aromatik yang mengandung gugus $-\mathrm{COOH}$ dan $-\mathrm{OH}$ (Stevenson, 1994).

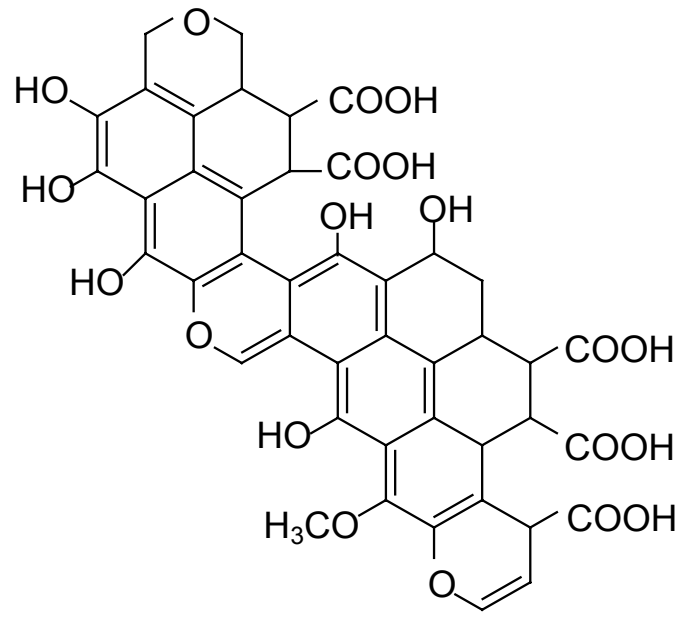

Gambar 2.1 Struktur hipotetik asam humat menurut Fuch (Stevenson, 1994)

Berdasarkan gugus fungsional reaktif hasil degradasi asam humat, maka struktur inti asam humat terdiri atas cincin aromatik, di-, atau trihidroksifenol yang dijembatani oleh -O-, $-\left(\mathrm{CH}_{2}\right)_{-},-\mathrm{NH}-$ dan :N-. Selain itu, gugus-gugus fungsional utama yang terdapat pada asam humat adalah gugus $-\mathrm{COOH},-\mathrm{OH}$ dan kuinon. Pada keadaan alami, molekul-molekul tersebut mengandung residu protein dan karbohidrat yang sebagian besar dihubungkan oleh ikatan kovalen pada struktur inti.

Struktur pertama yang menggunakan konsep tersebut 
dikemukakan oleh Dragunov (Konokova, 1966 dalam Stevenson, 1994) seperti terlihat pada Gambar 2.2. Pada struktur ini dapat dilihat cincin aromatis di- dan trihidroksilbenzena (1), nitrogen dalam bentuk siklis (2), nitrogen dalam rantai periperal (3) dan residu karbohidrat (4).

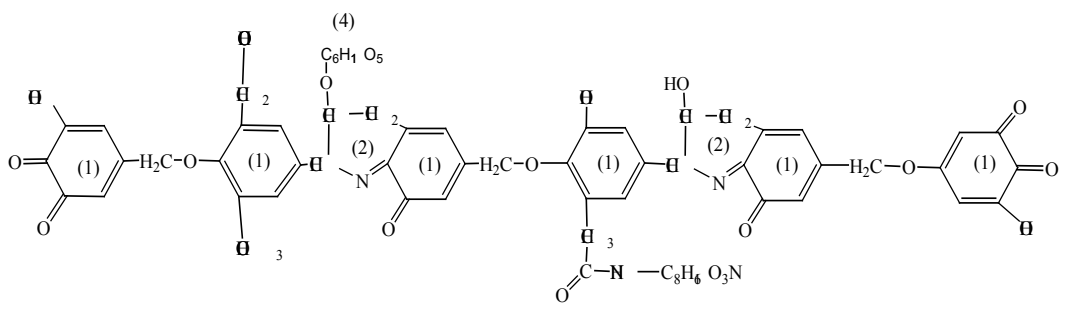

(3) (4)

Gambar 2.2 Struktur hipotetik asam humat menurut Dragunov memperlihatkan : 1) cincin aromatik, 2) nitrogen dalam bentuk siklis, 3) nitrogen dalam rantai periperal dan 4) residu karbohidrat.

Struktur lain dikemukakan oleh Flaig, dimana asam humat mengandung gugus - $\mathrm{OH}$ fenolat dalam jumlah cukup melimpah, tetapi gugus karboksilatnya relatif sedikit (Stevenson, 1994), ditunjukkan pada Gambar 2.3.

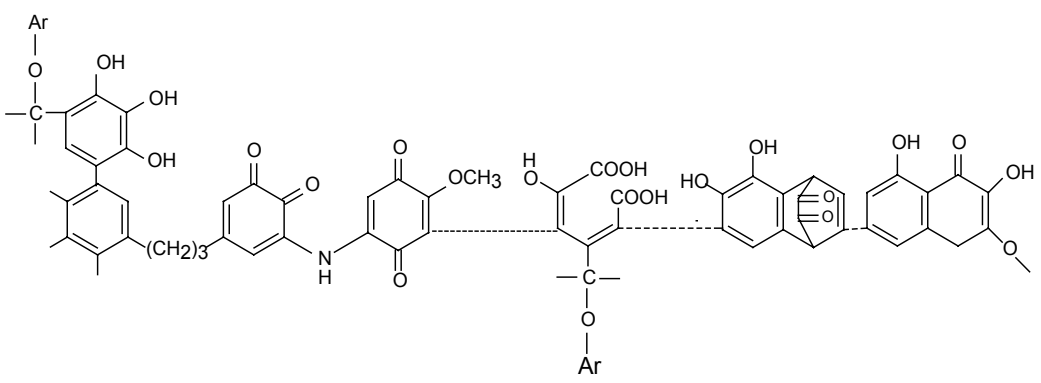

Gambar 2.3 Struktur hipotetik asam humat menurut Flaig (Stevenson, 1994)

Struktur asam humat yang saat ini dianggap memenuhi konsep-konsep yang telah ada dikemukakan oleh Stevenson (1994). Pada struktur hipotetik ini, asam humat mengandung gugus $-\mathrm{OH}$ fenolat, $-\mathrm{COOH}$ yang terikat pada cincin aromatik

122 Jurnal PHENOMENON, Volume 2 Nomor 1, November 2011 
dan kuinon yang dijembatani oleh nitrogen dan oksigen (Gambar 2.4).

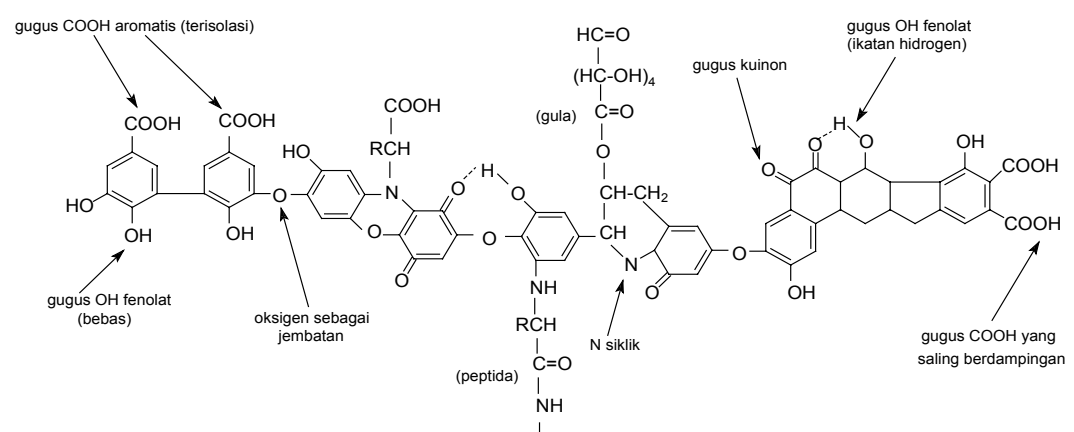

Gambar 2.4 Struktur hipotetik asam humat menurut

Stevenson

\section{Ekstraksi dan Isolasi Senyawa-senyawa Humat}

Isolasi senyawa-senyawa humat dari tanah pertama kali dilakukan oleh Achard (1786) yang mengekstraksi tanah gambut dengan alkali dan diperoleh endapan amorf pada saat pengasaman (Aiken dkk., 1985). Bahan yang larut dalam alkali dan tidak larut dalam asam ini selanjutnya dikenal sebagai asam humat.

Sejumlah metode isolasi/ekstraksi senyawa humat pada berbagai jenis sampel lingkungan, baik lingkungan tanah, perairan maupun sedimen telah dilaporkan oleh sejumlah peneliti. Stevenson (1982) dalam Aiken dkk. (1985) menyatakan bahwa ada beberapa kriteria metode ekstraksi senyawa humat dari tanah secara ideal yaitu : (1) metode yang digunakan untuk isolasi tidak menimbulkan perubahan bahan-bahan yang diekstraksi, (2) senyawa-senyawa humat yang terekstrak bebas dari kontaminan anorganik seperti lempung dan kation-kation polivalen, (3) proses ekstraksi berlangsung sempurna, dan dapat menggambarkan fraksi-fraksi dari seluruh rentang berat molekul, (4) metode bersifat universal, dapat diaplikasikan pada semua jenis tanah.

Senyawa humat tanah yang diekstraksi menggunakan laru- 
tan natrium hidroksida menghasilkan produk yang lebih besar (80\%) dibandingkan hasil ekstraksi menggunakan larutan garam netral natrium pirofosfat yang hasil ekstraksinya hanya berkisar 30\% (Stevenson, 1994). Asam humat dan fulvat larut dalam natrium hidroksida, sedangkan humin dan senyawa non-humat lainnya tidak larut. Untuk memperoleh asam humat dari larutan natrium hidroksida perlu diasamkan sampai $\mathrm{pH} \pm 2$ dengan menggunakan asam klorida. Asam humat mengendap dan asam fulvat tertinggal dalam larutan bersama molekul-molekul kecil lainnya seperti gula sederhana dan asam-asam amino (Gaffney dkk., 1996).

Setelah proses ekstraksi senyawa humat, proses selanjutnya adalah pemurnian senyawa humat tersebut dengan cara memisahkannya dari senyawa-senyawa non-humat. Pemurnian asam humat dilakukan dengan cara melarutkan asam humat hasil isolasi ke dalam larutan campuran 0,1 $\mathrm{N} \mathrm{HCl}$ dan 0,3 $\mathrm{N} \mathrm{HF}$. Kedua pereaksi tersebut berfungsi untuk memisahkan kontaminan berupa bahan-bahan anorganik dari asam humat terutama silika dan logam.

\section{METODE PENELITIAN}

\section{Isolasi Asam Humat}

Dua ribu gram tanah gambut diekstraksi dengan 20.000 $\mathrm{mL} \mathrm{NaOH} 0,1 \mathrm{~N}$ (perbandingan tanah dengan pelarut $1: 10$ ), digojog dengan shaker selama 24 jam di bawah kondisi atmosfer nitrogen. Supernatan yang bersifat alkalis dipisahkan dari residunya dengan cara disentrifugasi, kemudian diasamkan dengan larutan $\mathrm{HCl} 6 \mathrm{~N}$ hingga $\mathrm{pH} 1$ dan didiamkan selama 16 jam pada temperatur kamar, sehingga terbentuk dua lapisan yaitu lapisan atas berupa supernatan (asam fulvat fraksi I) dan lapisan bawah berupa endapan (asam humat). Supernatan asam fulvat dan asam humat terpresipitasi dipisahkan dengan cara disentrifugasi selama 10 menit dengan kecepatan 10.000 rpm. Padatan yang diperoleh merupakan asam humat kotor (crude humic acids) sehingga perlu pemurnian lebih lanjut. 


\section{Pemurnian Asam Humat}

Asam humat kotor (crude humic acids) yang diperoleh, dilarutkan ke dalam $2500 \mathrm{~mL}$ larutan $\mathrm{KOH} \mathrm{0,1} \mathrm{N} \mathrm{di} \mathrm{bawah} \mathrm{kon-}$ disi atmosfer nitrogen. Ke dalam larutan ditambahkan sejumlah tertentu garam $\mathrm{KCl}$ hingga konsentrasi ion $\mathrm{K}^{+}$dalam larutan tepat 0,3 M dan kemudian disentrifugasi dengan kecepatan 12.000 rpm selama 6 menit, sehingga terbentuk dua lapisan. Lapisan atas berupa supernatan (asam humat dan asam fulvat) dipisahkan dari pengotor padatan yang berada pada lapisan bawah dengan cara didekantir. Selanjutnya supernatan yang merupakan campuran asam humat dan asam fulvat diasamkan dengan larutan $\mathrm{HCl} 6 \mathrm{~N}$ hingga $\mathrm{pH} 1$ dan didiamkan selama 16 jam, sehingga dalam sistem terbentuk dua lapisan yaitu lapisan atas merupakan supernatan asam fulvat fraksi II dan lapisan bawah merupakan padatan asam humat. Supernatan dan endapan dipisahkan dengan cara disentrifugasi dengan kecepatan 12.000 rpm selama 6 menit. Padatan asam humat yang diperoleh dimasukkan ke dalam wadah plastik yang berisi larutan campuran 0,1 $\mathrm{N} \mathrm{HCl} /$ 0,3 N HF dan didiamkan selama 7 hari pada temperatur kamar. Endapan dan supernatan dipisahkan dengan cara disentrifugasi dengan kecepatan $12.000 \mathrm{rpm}$ selama 6 menit. Diambil endapannya yang merupakan asam humat murni. Proses pemurnian tersebut dilakukan sebanyak 2 kali. Dalam proses pemurnian tersebut banyak menggunakan $\mathrm{HCl}$ sehingga sangat mungkin asam humat banyak mengandung ion $\mathrm{Cl}^{-}$. Untuk menghilangkan ion $\mathrm{Cl}^{-}$dilakukan pembilasan dengan akuades secara berulang. Uji $\mathrm{Cl}^{-}$dilakukan dengan cara menambahkan larutan $\mathrm{AgNO}_{3}$ ke dalam air bilasan asam humat. Jika terbentuk endapan putih $\mathrm{AgCl}$, berarti di dalam asam humat tersebut masih mengandung ion $\mathrm{Cl}^{-}$sehingga perlu pembilasan lebih lanjut. Pembilasan dihentikan jika dalam air bilasan asam humat tidak terbentuk endapan putih dengan penambahan larutan $\mathrm{AgNO}_{3}$. Setelah selesai proses pemurnian, asam humat dikeringkan dengan freeze dryer. Asam humat yang diperoleh berbentuk serbuk coklat kehitaman. 


\section{Penetapan Kadar Abu Asam Humat}

Untuk mengetahui kemurnian asam humat hasil isolasi, asam humat kotor dan asam humat hasil pemurnian yang diperoleh ditetapkan kadar abunya. Ditimbang masing-masing sebanyak $100 \mathrm{mg}$ asam humat tanpa pemurnian, asam humat satu kali pemurnian, asam humat dua kali pemurnian, masing-masing dimasukkan ke dalam cawan porselin, kemudian dipanaskan dalam tungku (furnace) hingga temperatur $750^{\circ} \mathrm{C}$. Sesudah dipanaskan, ditimbang dan dicatat beratnya. Pengukuran kadar abu masing-masing sampel dilakukan tiga kali pengulangan.

\section{Karakterisasi Kandungan Gugus Fungsional Asam Humat}

Kandungan gugus fungsional asam humat yang ditentukan secara kuantitatif dalam penelitian ini adalah gugus karboksilat $(-\mathrm{COOH}),-\mathrm{OH}$ fenolat dan -OH alkoholat. Kandungan gugus $\mathrm{OH}$ fenolat ditentukan sebagai selisih antara keasaman total dan kandungan gugus - $\mathrm{COOH}$. Selanjutnya kandungan -OH alkoholat ditentukan sebagai selisih antara kandungan gugus $-\mathrm{OH}$ total dan gugus -OH fenolat (Stevenson, 1994).

\section{Penetapan Keasaman Total Asam Humat}

Ditimbang sebanyak $100 \mathrm{mg}$ asam humat murni dan dimasukkan ke dalam labu takar $100 \mathrm{~mL}$, lalu ditambahkan 20 $\mathrm{mL}$ larutan jenuh $\mathrm{Ba}(\mathrm{OH})_{2}$ sambil dialiri gas nitrogen. Setelah dialiri gas nitrogen, labu takar ditutup dan digojog selama 24 jam dengan shaker Marius Instrumen pada temperatur kamar. Secara simultan dilakukan pula terhadap larutan blangko yang mengandung $20 \mathrm{~mL}$ larutan jenuh $\mathrm{Ba}(\mathrm{OH})_{2}$. Suspensi yang terbentuk disaring menggunakan kertas saring Whatman 42 dan residu dibilas dengan akuades bebas $\mathrm{CO}_{2}$. Filtrat dan air bilasan di gabung lalu dititrasi secara potensiometri dengan larutan standar 0,25 N HCl hingga $\mathrm{pH} 8,4$. Percobaan tersebut dilakukan tiga kali pengulangan.

\section{Penetapan Kandungan Gugus Karboksilat}

Ditimbang sebanyak $100 \mathrm{mg}$ asam humat murni dan dimasukkan ke dalam labu takar $100 \mathrm{~mL}$, kemudian ditambahkan 10 
mL larutan $\mathrm{Mg}\left(\mathrm{CH}_{3} \mathrm{COO}\right)_{2} 0,5 \mathrm{M}$ dan $40 \mathrm{~mL}$ akuades bebas $\mathrm{CO}_{2}$. Secara simultan dilakukan pula terhadap larutan blangko yang mengandung $10 \mathrm{~mL}$ larutan $\mathrm{Mg}\left(\mathrm{CH}_{3} \mathrm{COO}\right)_{2} 0,5 \mathrm{M}$ dan $40 \mathrm{~mL}$ akuades bebas $\mathrm{CO}_{2}$, kemudian digojog dengan shaker selama 24 jam pada temperatur kamar. Suspensi yang terbentuk disaring dengan kertas saring whatman 42 , residu dibilas dengan akuades bebas $\mathrm{CO}_{2}$. Filtrat dan air bilasan digabung, kemudian dititrasi secara potensiometri dengan larutan standar $\mathrm{NaOH} 0,1$ $\mathrm{M}$ hingga $\mathrm{pH}$ 9,8. Percobaan tersebut dilakukan dengan tiga kali pengulangan.

\section{Penetapan Kandungan Gugus -OH Total}

Ditimbang sebanyak $100 \mathrm{mg}$ asam humat murni dan ditambah $5 \mathrm{~mL}$ campuran piridin dan asetat anhidirida (perbandingan 1:1), kemudian direfluk selama 3 jam di bawah kondisi atmosfer nitrogen. Campuran didinginkan dalam air, lalu disaring. Padatan yang diperoleh dibilas dengan akuades dan dikeringkan dalam kondisi vakum dengan bantuan silika gel. Ditimbang padatan kering berupa sampel yang terasetilasi sebanyak $50 \mathrm{mg}$, kemudian direfluk dengan $25 \mathrm{~mL}$ larutan $\mathrm{NaOH} 3 \mathrm{~N}$ selama 2 jam sambil dialiri gas nitrogen. Setelah didinginkan, ke dalam labu refluk ditambahkan $25 \mathrm{~mL}$ larutan $\mathrm{H}_{2} \mathrm{SO}_{4} 6 \mathrm{~N}$ dan $25 \mathrm{~mL}$ akuades bebas $\mathrm{CO}_{2}$ kemudian didestilasi. Volume campuran destilasi dipertahankan konstan dengan menambahkan $25 \mathrm{~mL}$ akuades. Destilat yang diperoleh dititrasi dengan larutan standar $\mathrm{NaOH}$ 0,01 N menggunakan indikator fenoftalin (pp). Prosedur yang sama dilakukan terhadap larutan blangko yang dilanjutkan dengan destilasi sampai kedua larutan sampel dan blangko mencapai volume yang sama. Percobaan tersebut dilakukan dengan tiga kali pengulangan.

\section{HASIL PENELITIAN DAN PEMBAHASAN}

Isolasi asam humat dari tanah gambut pada penelitian ini menggunakan metode ekstraksi alkali seperti yang direkomen- 
dasikan oleh International Humic Substances Society (IHSS) (Calderoni dan Schnitzer, 1984, dalam Tarchitzky dkk., 1993). Metode ini berlaku universal untuk semua jenis tanah dan pereaksi yang digunakan tidak merusak bahan yang diisolasi serta penanganannya relatif mudah dan sederhana (Tarchitzky dkk., 1993). Dalam penelitian ini, tanah gambut diekstraksi dengan larutan $\mathrm{NaOH}$ 0,1 M dengan perbandingan tanah : larutan $\mathrm{NaOH}$ adalah 1: 10 di bawah kondisi atmosfir nitrogen. Kondisi atmosfir nitrogen dimaksudkan untuk mencegah terjadinya reaksi autooksidasi gugus-gugus yang ada dalam asam humat saat berlangsung proses ekstraksi.

Asam humat yang diperoleh dalam penelitian ini berwarna coklat kehitaman, dengan rendemen sebesar $\pm 5,8 \%$. Asam humat hasil isolasi tanah gambut yang telah dimurnikan diidentifikasi secara spektroskopi inframerah, ditunjukkan pada Gambar 4.1.

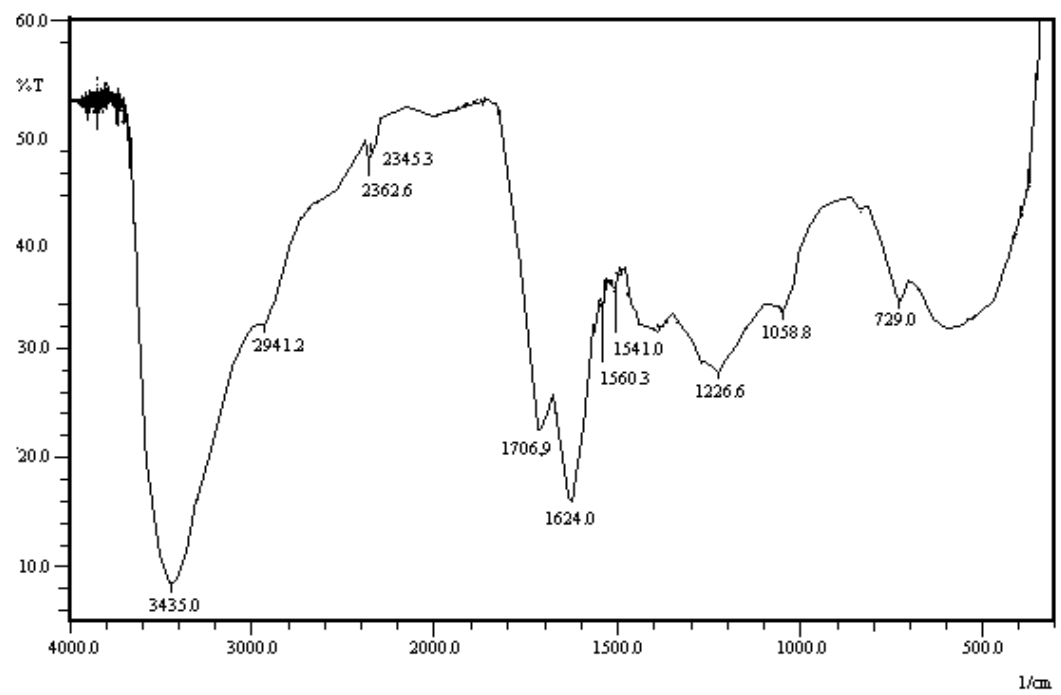

Gambar 4.1 Spektra inframerah asam humat hasil pemurnian

Interpretasi spektra inframerah asam humat hasil pemurnian yang tersaji pada Gambar 4.1 adalah sebagai berikut : serapan kuat melebar pada bilangan gelombang $3435,0 \mathrm{~cm}^{-1}$ menunjuk- 
kan vibrasi ulur -OH, serapan pada bilangan gelombang 2941,2 $\mathrm{cm}^{-1}$ mengidentifikasikan adanya vibrasi ulur $\mathrm{C}-\mathrm{H}$ alifatik. Pita serapan yang muncul pada bilangan gelombang $1706,9 \mathrm{~cm}^{-1}$ menunjukkan vibrasi ulur $-\mathrm{C}=\mathrm{O}$ dari gugus $-\mathrm{COOH}$. Bilangan gelombang ini khas untuk $-\mathrm{C}=\mathrm{O}$ dari gugus karboksilat akibat keterlibatan resonansi gugus $-\mathrm{C}=\mathrm{O}$ dalam $-\mathrm{COOH}$ sehingga sedikit lebih rendah dibandingkan bilangan gelombang serapan $-\mathrm{C}=\mathrm{O}$ pada gugus karbonil terisolasi $\left(1730 \mathrm{~cm}^{-1}\right)$. Pita serapan pada bilangan gelombang $1624,0 \mathrm{~cm}^{-1}$ diinterpretasikan sebagai $-\mathrm{C}=\mathrm{C}$ - aromatik atau $\mathrm{C}=\mathrm{O}$ (keton terkonjugasi) yang mengikat hidrogen. Selain itu, $-\mathrm{C}=\mathrm{C}$ - aromatik juga ditunjukkan dengan munculnya pita serapan lemah pada bilangan gelombang 1541,0 $\mathrm{cm}^{-1}$ dan $1560,3 \mathrm{~cm}^{-1}$. Vibrasi tekuk -OH dari -COOH dan vibrasi ulur - $\mathrm{C}-\mathrm{O}$ dari $-\mathrm{COOH}$ teridentifikasi dengan munculnya serapan pada bilangan gelombang $1226,6 \mathrm{~cm}^{-1}$. Vibrasi ulur -OH dari - $\mathrm{COOH}$ diperkuat dengan munculnya pita serapan pada bilangan gelombang 2345,3 $\mathrm{cm}^{-1}$ dan 2362,6 $\mathrm{cm}^{-1}$.

Bentuk spektra yang melebar pada bilangan gelombang $3435,0 \mathrm{~cm}^{-1}$ sebagai vibrasi ulur O-H dalam penelitian ini menunjukkan adanya pengaruh ikatan hidrogen pada senyawa humat. Munculnya spektra di sekitar bilangan gelombang $1050 \mathrm{~cm}^{-1} \mathrm{di}-$ duga sebagai senyawa polisakarida yang terdapat dalam asam humat. Selain itu, asam humat yang diisolasi dari tanah memiliki ciri khas yaitu munculnya spektra pada bilangan gelombang sekitar 950-1150 $\mathrm{cm}^{-1}$. Asam humat yang diisolasi dari sumber lain seperti danau dan sungai hampir tidak memberikan pita serapan pada bilangan gelombang ini.

Berdasarkan interpretasi spektra inframerah di atas dapat dinyatakan bahwa asam humat hasil penelitian ini didominasi gugus-gugus - $\mathrm{COOH}$ dan -OH. Dominasi gugus -OH ditandai dengan puncak serapan yang sangat karakteristik yaitu munculnya puncak serapan pada bilangan gelombang di sekitar 3435,0 $\mathrm{cm}^{-1}$ sebagai vibrasi ulur O-H. Sedangkan dominasi gugus $\mathrm{COOH}$ ditandai dengan munculnya puncak serapan pada bilangan gelombang 1226,6 $\mathrm{cm}^{-1}$ sebagai vibrasi ulur gugus -OH dan -C-O dari gugus $-\mathrm{COOH}$, serta pita serapan yang muncul pada 
bilangan gelombang $1706,9 \mathrm{~cm}^{-1}$ yang menunjukkan vibrasi ulur gugus $-\mathrm{C}=\mathrm{O}$ dari gugus $-\mathrm{COOH}$.

Pada spektra inframerah asam humat hasil pemurnian tidak tampak puncak pada bilangan gelombang sekitar $1380 \mathrm{~cm}^{-1}$. Hal tersebut menunjukkan bahwa asam humat yang diperoleh sudah cukup murni (terbebas dari ion-ion logam). Hal ini terjadi karena pada tahap pemurnian digunakan larutan $\mathrm{HCl}$ dan $\mathrm{HF}$ yang diyakini mampu membebaskan asam humat dari pengotor bahan-bahan organik (Stevenson, 1994). Selain itu, $\mathrm{HCl}$ telah terbukti mampu menghidrolisis senyawa-senyawa yang mengandung nitrogen, karbohidrat dan bahan-bahan anorganik lain yang terserap pada asam humat (Riffaldi dan Schnitzer, 1972 dalam Stevenson, 1994). Dugaan ini diperkuat dengan hasil penetapan kadar abu asam humat tanpa pemurnian dan asam humat yang telah dimurnikan. Hasil penetapan kadar abu asam humat tanpa pemurnian dan asam humat yang telah dimurnikan berturut-turut adalah 11,43 dan 0,50\% (b/b). Tingginya kadar abu asam humat tanpa pemurnian yang diperoleh dalam penelitian ini disebabkan karena asam humat tersebut kemungkinan masih mengandung bahan-bahan anorganik seperti lempung dan logam-logam.

\section{Karakterisasi Kandungan Gugus Fungsional Asam Humat Ta- nah Gambut}

Hasil analisis kandungan gugus fungsional asam humat yang diekstraksi dari tanah gambut yang berasal dari Desa Sambutan, Kecamatan Samarinda Ilir, Kabupaten Samarinda tersaji pada Tabel 4.1. Hasil penelitian menunjukkan bahwa kandungan gugus - $\mathrm{COOH}$ relatif lebih tinggi dibandingkan dengan gugus $-\mathrm{OH}$ fenolat dan $-\mathrm{OH}$ alkoholat. Hal ini merupakan akibat dari asam humat sebagai hasil biodegradasi lanjut dari lignin. Menurut teori Lignin tentang pembentukan asam humat yang dikemukakan oleh Flaig (Stevenson, 1994), gugus -COOH yang terdapat pada asam humat merupakan hasil oksidasi rantai samping lignin seperti $-\mathrm{CH}_{2} \mathrm{OH}$. Selain itu, gugus - $\mathrm{COOH}$ dapat pula bersumber dari hasil pemecahan cincin komponen aroma- 
tik lignin.

Tabel 4.1 Kandungan gugus fungsional asam humat tanah gambut

\begin{tabular}{|c|c|c|c|}
\hline \multirow{2}{*}{ No. } & \multirow{2}{*}{ Gugus Fungsional } & \multicolumn{2}{|c|}{$\begin{array}{c}\text { Kadar dalam asam humat } \\
\text { (cmol/kg) }\end{array}$} \\
\cline { 3 - 4 } & & Penelitian ini & $\begin{array}{c}\text { Penelitian } \\
\text { Schnitzer }\end{array}$ \\
\hline \multirow{2}{*}{1} & Keasaman total & 715,8 & $570-890$ \\
2 & Gugus hidroksil-OH & & t.d \\
& a. Fenolat & 289,6 & t.d \\
3 & b. Alkoholat & 37,0 & $270-350$ \\
4 & -OH total & 326,6 & $150-570$ \\
\hline
\end{tabular}

t.d = tidak ditetapkan

\section{Kandungan Keasaman Total}

Salah satu ciri asam humat adalah memiliki keasaman total lebih rendah dibandingkan asam fulvat. Keasaman total atau kapasitas tukar asam humat disebabkan oleh adanya proton yang dapat terdisosiasi atau pelepasan ion-ion $\mathrm{H}^{+}$pada gugusgugus karboksilat dan gugus hidroksil fenolat. Dalam penelitian ini penetapan kandungan keasaman total asam humat menggunakan metode barium hidroksida (Baryta Absorption Methods). Metode tersebut menggunakan pendekatan titrasi potensiometri dan didasarkan pada pelepasan ion $\mathrm{H}^{+}$dari gugus-gugus fungsional asam humat yang bersifat asam. Sampel direaksikan dengan $\mathrm{Ba}(\mathrm{OH})_{2}$ berlebih, sisa $\mathrm{Ba}(\mathrm{OH})_{2}$ yang tidak bereaksi dengan sampel dititrasi secara potensiometri dengan larutan standar asam $(\mathrm{HCl} \mathrm{0,25} \mathrm{N)} \mathrm{hingga} \mathrm{pH} 8,4$. Reaksi yang terjadi dimodelkan sebagai berikut (Stevenson, 1994) : 


$$
\begin{aligned}
& 2 \mathrm{RH}+\mathrm{Ba}(\mathrm{OH})_{2 \text { (berlebih) }} \longrightarrow \mathrm{R}_{2} \mathrm{Ba}+2 \mathrm{H}_{2} \mathrm{O} \\
& \mathrm{Ba}(\mathrm{OH})_{2 \text { (sisa) }}+2 \mathrm{HCl} \longrightarrow \mathrm{BaCl}_{2}+2 \mathrm{H}_{2} \mathrm{O}
\end{aligned}
$$

Dimana $\mathrm{R}$ adalah makromolekul dan $\mathrm{H}$ adalah proton gugus - $\mathrm{COOH}$ atau $-\mathrm{OH}$ yang bersifat asam.

Keasaman total asam humat tanah gambut yang diperoleh dalam penelitian ini sebesar $715,8 \mathrm{cmol} / \mathrm{kg}$. Menurut Schnitzer, secara umum keasaman total asam humat tanah yang bersifat asam berkisar 570-890 cmol/ kg (Stevenson, 1994). Hal ini berarti ada kesusaian antara hasil penelitian dengan hasil yang dikemukakan oleh Schnitzer.

\section{Kandungan Gugus Karboksilat (-COOH)}

Sejumlah metode tersedia untuk penetapan jumlah gugus karboksilat dalam asam humat, misalnya metode pertukaran ion, dekarboksilasi, iodometri, esterifikasi, dan prosedur Ca-asetat. Pada penelitian ini, digunakan metode Ca-asetat yang di adaptasi dari prosedur Schnitzer (Stevenson, 1994). Metode tersebut menggunakan pendekatan titrasi potensiometri dan didasarkan pada pertukaran ion. Berdasarkan metode tersebut, sampel direaksikan dengan Ca-asetat, kemudian asam asetat yang dibebaskan dititrasi secara potensiometri dengan larutan standar basa $\mathrm{NaOH}$ 0,1 M hingga $\mathrm{pH}$ 9,8. Reaksi yang terjadi merupakan suatu reaksi yang menghasilkan pembentukan dan pelepasan asam asetat (Tan,1998):

$$
2 \mathrm{R}-\mathrm{COOH}+\mathrm{Ca}\left(\mathrm{CH}_{3} \mathrm{COO}\right)_{2} \longrightarrow \mathrm{Ca}(\mathrm{R}-\mathrm{COO})_{2}+2 \mathrm{CH}_{3} \mathrm{COOH}
$$

Menurut Schnitzer, kandungan gugus - $\mathrm{COOH}$ asam humat tanah yang bersifat asam berkisar $150-570 \mathrm{cmol} / \mathrm{kg}$ (Stevenson, 1994). Hasil penelitian kandungan gugus $-\mathrm{COOH}$ dalam asam humat tanah gambut sebesar $426,2 \mathrm{cmol} / \mathrm{kg}$. Hal ini berarti ada kesesuaian kandungan gugus - $\mathrm{COOH}$ yang diperoleh dari penelitian ini dengan kandungan gugus $-\mathrm{COOH}$ yang dikemukakan 
oleh Schnitzer.

\section{Kandungan $\mathrm{OH}$ Total}

Penetapan - $\mathrm{OH}$ total dalam penelitian ini menggunakan metode asetilasi (Metode Asetilasi dengan Asetat Anhidrida). Gugus $-\mathrm{OH}$ total yang ditentukan dengan metode asetilasi adalah gugus - $\mathrm{OH}$ fenolat dan alkoholat.

Asam humat tanah gambut direaksikan dengan asetat anhidrida, kemudian direfluk dalam medium piridin membentuk makromolekul ester asetat (sampel terasetilasi) dan asam asetat sebagai hasil samping. Reaksi yang terjadi dapat dimodelkan sebagai berikut (Stevenson, 1994) :

$\mathrm{R}-\mathrm{OH}+\left(\mathrm{CH}_{3} \mathrm{CO}\right)_{2} \mathrm{O} \longrightarrow \mathrm{CH}_{3} \mathrm{COOR}+\mathrm{CH}_{3} \mathrm{COOH}$

Makromolekul ester asetat yang telah kering direfluk dengan $\mathrm{NaOH}$. Setelah direfluk, larutan campuran tersebut direaksikan dengan $\mathrm{H}_{2} \mathrm{SO}_{4}$ dalam medium air lalu didestilasi. Destilat yang diperoleh dititrasi dengan larutan standar basa $(\mathrm{NaOH}$ 0,01 N) dengan menggunakan indikator fenolftalin.

Menurut Schnitzer, kandungan gugus -OH total asam humat tanah yang bersifat asam berkisar 270-350 cmol/ $\mathrm{kg}$ (Stevenson, 1994). Sedangkan kandungan gugus $-\mathrm{OH}$ total dalam asam humat tanah gambut yang diperoleh dalam penelitian ini sebesar 326,6 cmol/ $\mathrm{kg}$. Hal ini berarti ada kesesuaian antara kandungan gugus - $\mathrm{COOH}$ yang diperoleh dari penelitian ini dengan kandungan $\mathrm{OH}$ total yang dikemukakan oleh Schnitzer.

\section{Kandungan Gugus -OH Fenolat dan -OH Alkoholat}

Seperti telah diuraikan dalam tinjauan pustaka bahwa kandungan gugus $-\mathrm{OH}$ fenolat merupakan selisih dari keasaman total dengan kandungan gugus - $\mathrm{COOH}$. Sedangkan gugus $-\mathrm{OH}$ alkoholat merupakan selisih dari kandungan -OH total dengan -OH fenolat. Dari hasil penelitian diperoleh kandungan $\mathrm{OH}$ fenolat sebesar 289,6 cmol/ $\mathrm{kg}$ dan $-\mathrm{OH}$ alkoholat sebesar $37,0 \mathrm{cmol} / \mathrm{kg}$. Hasil penelitian yang telah dilaporkan sejumlah 
peneliti menunjukkan bahwa umumnya kandungan gugus $-\mathrm{OH}$ fenolat lebih tinggi dari -OH alkoholat.

\section{KESIMPULAN}

Berdasarkan hasil penelitian dan pembahasan, dapat diambil kesimpulan sebagai berikut :

1. Data spektra inframerah asam humat murni menunjukkan gugus fungsional utama dalam asam humat hasil isolasi tanah gambut adalah gugus $-\mathrm{COOH}$ dan $-\mathrm{OH}$.

2. Analisis secara kuantitatif menunjukkan kandungan gugus $\mathrm{COOH}$ sebesar $426,2 \mathrm{cmol} / \mathrm{kg}$, $-\mathrm{OH}$ total sebesar $326,6 \mathrm{cmol} /$ $\mathrm{kg}$ yang terdiri atas $-\mathrm{OH}$ fenolat sebesar $289,6 \mathrm{cmol} / \mathrm{kg}$ dan -OH alkoholat sebesar $37,0 \mathrm{cmol} / \mathrm{kg}$. 


\section{DAFTAR PUSTAKA}

Aiken, G.R., McKnight, D.M.,Wershaw, R.L. dan P. MacCarthy, P., 1985, "Humic Substance in Soil, Sediment and Water" : Geochemistry, Isolation, and Characterization, John Wiley \& Sons, New York.

Gaffney, J.S., Marley, N.A., Clarck, S.B., 1996, Humic and Fulvic Acids : Isolation, Structure and Environmental Role, American Chemical Society, Washington, DC.

Gosh, K., dan Schnitzer, M., 1980, “Macromolecular Structures of Humic Substances", Soil Science, 129

Hayes, M.B., dan Himes, F.L., 1986, “Nature and Properties of Humus-Mineral Complexes", In : "Interaction of Soil Mineral with Natural Organics and Microbes" (P.M. Huang dan M.Schnitzer), Soil Sci. Soc. Am. Special Publ., 17, Soil Sci. Am., Madison, WI : 103-158.

Ishiwatari, R., 1985, “Geochemistry of Humic Subtances in Lake Sediments" (dalam Aiken, dkk, 1985, Humic Subtances in Soils, Sediment and Water: Geochemistry, Isolation, and Characterization, John Wiley \& Sons, New York.

Manahan, S.E., 2000, "Environmental Chemistry", Seventh Edition, Willard Grant Press, Boston.

Sanchez-Cortez, S., Francioso, O., Garcia-Ramos, J.V., Marzadori, C., and Gessa, C.C.C., 2000, “Formation of Humic-like 
Atik Rahmawati

substances from Phenols by means SERS Spectroscopy, p.121, In : Proceedings $10^{\text {th }}$ International Meeting of the International-Humic Substances Society, IHSS 10, 24-28 July 2000-Touluse (France).

Schnitzer, M., 1986, "Pengikatan Bahan Humat oleh Koloid Mineral Tanah", (dalam Huang, P.M, dan Schnitzer, M., 1986, "Interaksi Mineral Tanah dengan Organik Alami dan Mikroba", Terjemahan : Goenadi, D.H., 1997), Gadjah Mada University Press, Yogyakarta.

Stevenson, F.J., 1994, "Humus Chemistry : Genesis, Composition, Reactions", John Wiley \& Sons Inc., New York.

Tan, K.H., 1998, “Dasar-dasar Kimia Tanah", Gadjah Mada University Press, Yogyakarta.

Tarchitzky, J., Y.Chen., dan A.Banin, 1993, “Humic Subtances and $\mathrm{pH}$ Effects on Sodium-and Calcium-Montmorillonite Flocculation and Dispersion", Soil Science Soc. Am. J, 57 : 367-372.

136 Jurnal PHENOMENoN, Volume 2 Nomor 1, November 2011 